\title{
Roles of Feedback to English Writing Improvement: Thai EFL Novice Writers in Higher Education
}

\section{Thitirat Wichanpricha}

\author{
Department of Western Language, \\ Rajamangala University of Technology Lanna Tak, \\ Thailand
}

DOI: https://doi.org/10.36941/jesr-2020-0115

\begin{abstract}
Writing has been the most difficult skill among EFL students for several decades. It inevitably promotes writing feedback and approaches to English writing classroom to minimize students' errors in their writing draft revision. Hereby, the current study aimed at investigating perceptions towards the three writing features: vocabulary, grammar, and content, and examining the differences of the three assessments including teacher feedback, peer feedback, and self-correction. In addition, the teacher feedback preference as implicit and explicit feedback was determined as well. Participants were 32 first-year undergraduate students majoring in English for International Communication at Rajamangala University of Technology, Lanna Tak. Thailand. The current study employed a mixed-method research approach. Questionnaires and open-ended questions were utilized as research tools. Participants were assigned three genres of writing paragraphs. It took 15 consecutive weeks in providing three different feedback to purposive samples. For every assignment, their peers corrected their first drafts and then they rechecked and edited their output by their own decision. Afterward, the teacher provided both implicit and explicit feedback on the revision process. The data obtained were quantitatively analyzed for mean, standard deviation, and a paired sample t-test which have been deployed to the differences among the three feedback. Correspondingly, all written responses were thematically grouped and transcribed into frequency and percentage. The findings indicated that students mostly expected the teacher to edit their misused words, grammatical errors, and ideas on their drafts. As for the three feedback, most beginning writers particularly believed that teacher feedback, which was followed by self-correction and peer feedback, was much necessary for writing improvement and teachers should edit their redrafts explicitly in an EFL writing classroom.
\end{abstract}

Keywords: teacher feedback, peer feedback, self-correction, EFL novice writers

\section{Introduction}

\subsection{Background of the study}

Writing has been one of the most prominent English language skills in ESL/EFL classrooms (Ahmadi, Maftoon \& Mehrdad, 2012; Fareed, Ashraf \& Bilal, 2016). English writing obviously appears to be a crucial mediation to convey opinions and thoughts in literate communities and across the globe (Tangkiengsirisin \& Kalra, 2016). Nonetheless, foreign language learners found that writing in English is much more difficult than other English skills (Phuket \& Othman, 2015) since a good paragraph primarily needs a topic sentence, supporting ideas, and conclusion (Wirantaka, 2016). Besides, spelling, 
capitalization, transition words, punctuations, content, and organization are essential elements at the beginning of paragraph writing (AlTameemy \& Daradkeh, 2019). These are likely to be feasible barriers that hinder EFL student writers from English writing development. On top of that, writing process and practice, which include four underlying steps: pre-writing, drafting, revising, and rewriting, enable students to strengthen and improve their writing skills (Zemach \& Rumisek, 2018). To develop and revise written works into a better and directed approach, corrective feedback is a useful central scaffolding for writing pedagogy to contribute to students either explicit or implicit feedback (AbuSeileek \& Abualsha'r, 2014) and provide quality information for writing improvement. According to a study of Bitchener and Ferris (2012), it was suggested that correction was pivotal since it expectedly supported students to administer syntactic and linguistic errors of English as their target language. With regard to writing instruction, language teachers possibly acted as a guide, facilitator, as well as feedback provider while students were undertaking writing steps (Ekşi, 2012). The teacher feedback to a piece of writing is to improve the quality of the paragraph; however, it might not infer that one particular approach would be the most effective revision of writing. Peer feedback is widely utilized in foreign and second language writing courses (Allen \& Mills, 2014). Edwards and Liu (2018) pointed out that student writers realize that explanation of teacher is not the only one source of feedback but also peer evaluation that provides feedback to one another. They could possibly give and receive certain new ideas on their redrafting. Promoting the success of lifelong students, it can be challenging for writing pedagogy. Self-assessment in writing illustrates a fruitful approach to encourage students' writing accomplishment (Nielsen, 2012). Several educational pieces of research claimed that highly effective feedback has derived from self-evaluation when gathering information (Hyland \& Hyland, 2006). All these three domains of feedback in English writing seem to inevitably be a constructive instructional method to improve students' EFL writing more effectively.

\subsection{Statement of the problem}

In Thai educational context, several writing courses have been embedded in the syllabus not only at secondary schools but also at tertiary level. Regarding many universities, they undeniably provide writing subjects as compulsory courses, which students have to pass prerequisite ones to be able to enroll in other advanced writing courses. According to the curriculum of English for International Communication (EIC) at Rajamangala University of Technology Lanna Tak, Thailand, every EIC student needs to succeed in three writing courses comprising paragraph writing, essay writing, and academic writing before graduation. Nonetheless, writing has been still determined the most complicated skill for EFL students (Sommanochai \& Meesri, 2018; Tongjean, Chusanachoti \& Makanong, 2019) due to the fact that they must have language competence especially grammar structure and vocabulary (Kaur, 2015) to separately organize and express their thoughts through understandable paragraph underlying topic assigned. Hence, lacking of lexical and grammatical knowledge demotivate them in writing effectively and creatively. Besides, most of the students have encountered written corrective feedback from the teacher, and unpleasant results triggered them less keen on English writing tasks (Watcharapunyawong \& Usaha, 2013). Teaching writing in a sizable undergraduate classroom would be an onerous burden for the teacher in providing written feedback. In other words, it is merely unmanageable dealing with feedback to a large number of students. Apart from this, Thai EFL students are expected to tackle a lot of writing aspects as well as generate writing paragraphs on their own for 15 weeks. The teacher feedback might not be the only approach to student's writing revision. As for the Thai EFL writing course, Judto (2014) emphasized that students' English proficiency was not related to feedback preferences. Her findings indicated that students were desirable to teacher feedback than other two feedback, including peer feedback and self-revision. Nevertheless, they employed teacher comments without any uptake on particular matters. When being compared to peer feedback, it seemed to be more understandable since they had many chances to talk over with their classmates freely and they also had self-correction based on specific writing checklist and rubrics. Studies in the areas of feedback on writing of beginning writers might be carried out 
extensively; however, it has still received results inconclusively. The current study investigates the possibility among the three types of writing revisions: teacher feedback, peer feedback, and selfcorrection. It has widely led to an alternative pedagogical implication to scaffold EFL students' writing drafts and ease teacher's heavy working load.

\section{Review of Literature}

\subsection{Studies offeedback}

Over a decade, several existing studies have continuously investigated teacher feedback (Han \& Hyland, 2015; Mahfoodh, 2017; Zhang \& Hyland, 2018; Zheng \& Yu, 2018), peer feedback (Landry, Jacobs \& Newton, 2014; Patchan, Schunn \& Correnti, 2016), and self-directed feedback (Amelia, 2020; Nielsen, 2012). Importantly, written corrective feedback was expected to broaden learners' insights on identifying their writing errors and tracing the syntactical and lexical functions of English (Bitchener \& Ferris, 2012). With regard to Anderson (1993), he suggested three stages in learning language process including the cognitive stage (a description of procedure being learned), associative stage (a method for performing skill being worked out), and autonomous stage (skill turning to be more quickly and automatic). He believed that practice eventually led to automatization, for example, beginning writers firstly perceived the rule of subject-verb agreement that an -s must be added to the verb after the third singular person and then they realized how to add an -s when the context requires it. Thus, they could add an -s more automatically. It could be concluded that the writing achievement of novice writers needs much more practice and learn from linguistics errors when they received implicit as well as explicit feedback from their teacher and peers. Nonetheless, autonomous self-correction has been more likely to emerge in proficient writers (Amelia, 2020).

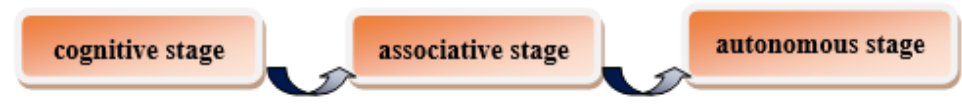

Figure 1. Three Stages of Language Learning Process

\subsubsection{Teacher feedback studies}

Teacher written correction continues playing a central role in a Foreign Language (FL) and Second Language (L2) writing classes (Hyland \& Hyland, 2006). There have been plenty of studies that determined students' attitudes and preferences in various circumstances.

Hosseiny (2014) examined direct and indirect written corrective feedback in improving Iranian students' writing skill. All sixty pre-intermediate students were divided into three equal groups. The first group was a control group with direct feedback provided while the second one was an indirectfeedback group. The third group was the one with no feedback. She reported that the direct feedback group achieved better result than other groups. There was a significant difference between the indirect feedback group and the group with no feedback. However, the direct and the indirect feedback groups were not statistically significant.

Ahmadi, Maftoon \& Mehrdad (2012) compared the effects of coded and uncoded feedback on EFL students in Advanced Writing classes. To investigate their composition development, they were randomly assigned to three groups: a control group, a coded feedback experimental group, and an uncoded feedback experimental group. The study was conducted in seven weeks. The result asserted that a significant difference in the uncoded feedback group was over the coded feedback and no feedback groups.

Moreover, Tangkiengsirisin \& Kalra's (2016) study traced the perceptions of direct and indirect 
written corrective feedback in Thai university context. Two types of feedback were provided on four different business letter writing assignments: persuasive, informative, negative, and positive letter writing. The finding found that the direct corrective feedback manifested positive contribution compared to the indirect feedback group that perceived negatively.

Other teacher feedback studies gave attention to three main dimensions including cognitive, behavioral, and affective engagements of students (Han \& Hyland, 2015; Zheng \& Yu, 2018). The results claimed that teachers had to realize students' beliefs and backgrounds to monitor written feedback strategies and encourage students' engagement in writing feedback. In case of lower-proficiency students, they negatively perceived indirect feedback due to insufficient understanding of written corrective feedback in terms of cognitive and behavioral engagement. It could contribute a better insight to the dynamic nature of EFL lower-proficiency students' engagement with teachers' written feedback.

\subsubsection{Peer feedback studies}

Peer feedback has been widely employed in foreign and second language writing (Allen \& Mills, 2014). It refers to peer response, peer review, and peer evaluation (Edwards \& Liu, 2018) that have been defined as a collaborative activity among classmates. The advantage of peer feedback according to the cognitive domain, students could exchange new perspectives on redrafts (Yastıbaş \& Yastıbaş, 2015). Their study monitored the effect of peer feedback on Turkish EFL students' writing anxiety. Mixed methods research design was utilized in the study which suggested that peer feedback reduced their writing anxiety and increased confidence during collaborative peer revision.

Additionally, Allen \& Katayama's (2016) study focused on learners' proficiency and perceptions of six undergraduate Japanese learners of English. Their results revealed that differences in language proficiency of peers turned out to be essential factors of giving and receiving feedback. Proficient peers could engage in more advice while low proficient peers could not. Higher proficient learners tended to pay attention to language use rather than content as well.

Yu \& Hu (2017) investigated two Chinese EFL undergraduates' peer feedback practices and factors. The findings manifested variations in peer feedback. Two participants exemplified different feedback practices in terms of values and beliefs, goals and motives, and feedback experience. This is in line with the study of Kuyyogsuy (2019) which adopted an embedded experimental design to elicit twenty-one undergraduate students' attitudes towards peer feedback by five-point Likert scale questionnaires. Her results affirmed that students who perceived peer revision achieved at high levels positively underlying four domains comprising writing process, affective strategies, critical thinking skills, and social interaction ability. They could handle peer feedback process more successfully along with better grammar structure. Furthermore, peer feedback promoted critical thinking and social skills by dealing with redrafting collaboratively.

\subsubsection{Self-correction studies}

Studies in the fields of self-correction, self-directed feedback, or self-assessment have steadily increased in ESL and EFL classrooms (Vasu, Ling \& Nimehchisalem, 2016). Self-correction is a procedure involving students making their judgment on learning namely their language learning outcomes and achievement (Belachew, Getinet \& Gashaye, 2015). Their study determined perception and practice of fifty EFL undergraduate learners as well as ten teachers towards self-assessment in English writing. Students were assigned four consecutive writing and self-assessment checklist ratings as excellent, good, fair, poor, and very poor. Teachers who have taught English writing courses at tertiary level were interviewed. The findings asserted that not only teachers but also students had a positive attitude towards self-assessment in writing. Many teachers have not experienced self-assessment in writing courses; hence they believed that students could not eventually assess their writing tasks on their own.

Correspondingly, Amelia's (2020) study employed a mixed-method research design to determine 
undergraduate students' perceptions of utilizing self-directed feedback in writing. Twenty-three students majoring in English were asked to contribute their thoughts through questionnaires and interviews. The results reported that the use of self-directed feedback in writing class was far more positive. As for students' reflections through the interview, most of them believed that the best feedback in writing assignments was the teacher feedback. Apart from this, students who could deal with self-directed feedback were able to attain maximum results of learning. The proficient students were provided self-directed feedback while the less proficient ones steadily edited their writing tasks by following teacher feedback.

In an experimental study of self-assessment in EFL writing conducted by Honsa (2013), students in the control group did not get involved in self-assessment training; however, those in the experimental group were trained to self-assess their essays. This is in line with the experimental study of Meihami and Varmaghani (2013). The results of both studies manifested that the experimental group had a significant improvement in writing whereas the writing progress in the control group did not have a significant difference. It could assure that self-assessment enhanced students' writing ability. There were also some difficulties to the students' self-assessment in writing including time constraint, inadequate language ability as well as first language interference.

\subsubsection{Comparative feedback studies}

Some studies monitored peer feedback and teacher feedback, for example, Ekşi (2012) and Maarof, Yamat, \& Li (2011) reportedly suggested that most students had a positive attitude towards a combination of two feedback in English wring courses. When deeply investigating two separated groups of students comprising peer-reviewing group and a given teacher feedback group, it mostly appeared identical writing achievements. Ruegg's (2015) findings revealed that the peer feedback was more general while the teacher feedback was more specific. Teacher feedback frequently enabled students to misunderstand on redrafts compared to peer feedback that was more successful in writing revisions. Furthermore, Amelia, Latief, and Irawati (2018) traced a combination of peer and selfdirected feedback of EFL high proficient students on writing ability. Their results asserted that two feedback training groups had better improvement in writing tasks than without peer and self-directed feedback group. Hence, providing the two feedback was suggested to proficient students. Cahyono and Rosyida (2016) compared three groups of Indonesian students consisted of a given peer feedback group, a self-correction group, and a no feedback group. The findings showed that students who tackled peer feedback and self-correction group along with a guideline sheet had significantly better writing outcomes than without any feedback in another group. It was highly recommended to promote peer feedback and self-correction based on guideline sheets to EFL writing classrooms.

Owing to the aforementioned comparative studies, they have contributed understandable and insightful results that shed light on the role of self-correction, peer feedback, and teacher feedback in students' writing development in ESL and/or EFL context. Nevertheless, there were a few studies of differences among three feedback that have been examined, particularly Thai EFL novice writers who were less explored individually. Therefore, the present study determined several perspectives of three different feedback in Thai EFL writing classroom.

\section{Research Questions}

1. To what extent do students perceive the three writing domains of teacher feedback?

2. Is there a significant difference among three types of feedback?

3. Is there a significant difference between an implicit and an explicit feedback? 


\section{Method}

\subsection{Research Design}

A mixed-method approach was deployed to the present study, including both quantitative and qualitative data.

Twenty items and five open-ended questions were adopted to ascertain students' perceptions when they entirely dealt with three modes of writing and completely underwent three domains of feedback: peer feedback, self-correction, and teacher feedback. The study was manipulated within 15 weeks in the second semester, academic year 2019.

\subsection{Participants of the Study}

The participants were 32 first-year students majoring in English for International Communication at Rajamangala University of Technology Lanna, Tak (RMUTL Tak). They were selected as a purposive sampling including males and females who were between 18 to 25 years old. They have already enrolled and passed two compulsory courses comprising English Structure and English Grammar for Communication. According to their English study background, they have never experienced in giving and getting feedback on writing. The current study particularized and focused on individual student in terms of his reflections on preference and benefits of feedback in writing revisions. It, therefore, explored a small number of participants. Before participating in data collection procedures, the research consent forms were distributed and signed.

\subsection{Instrument}

\subsubsection{Questionnaire of Feedback}

The feedback questionnaire consisted of two parts: Part I involved students' perceptions of teacher feedback, peer feedback, and self-correction, which entirely contained twenty items being designed on a Likert scale response using a five-interval scale of strongly disagree, disagree, unsure, agree, and strongly agree based on the numbers 1, 2, 3, 4, 5 where the statement checked strongly disagree measured at 1 while strongly agreed measured at 5 respectively. Part II included five open-ended questions as follows:

1. What three writing features do you find useful for your writing drafts?

2. According to teacher feedback, what topologies of writing correction would be meaningful?

3. To what extent would peer feedback improve your writing revision?

4. How well self-correction would help you minimize writing errors and ambiguity?

5. Among teacher feedback, peer feedback, and self-correction, which one(s) would strengthen your writing drafts better?

\subsubsection{Validity and Reliability of the Questionnaire}

To measure the validity of the questionnaire, the contents were administered by three experts in English language teaching field and research methodology. Therefore, all questionnaire items were determined by tool of the Index of Item-Objective Congruence (IOC) (Tuntavanitch \& Jindasri, 2018). As for twenty items in Part $I$, the contents validated at 0.85 as well as the validity of the contents in Part II was at 0.89 . The IOC value should be valued over 0.5 in every item and more than 0.7 as an overall value. Hence, all items in two parts were considered relevant to the objectives. The questionnaire then piloted to 20 undergraduate students who have studied writing courses. The Cronbach's alpha reliability coefficient of the questionnaire was significantly at 0.89 . 
All participants were introduced to the main purposes of the study. They have comprehensively mastered the process of paragraph writing, types of brainstorming, and editing during week 1-4. In this study, participants were assigned to write up three different modes of writing, namely, describing a person, comparison \& contrast, and problems \& solutions at least 150 words for each. To attain the effective results, they were trained to provide their comments to their friends as well as to revise their drafts by themselves. As for peer feedback and self-correction, paragraph checklists (MiraCosta College, 2012) were distributed to all participants when they have completed their first drafts. They firstly swopped writing drafts with their classmates and later revised their writing themselves. They finally submitted their final drafts to the teacher who contributed suggestions in terms of content, sentence structure \& vocabulary, paragraph legibility, and grammar mechanics. To provide clarity on the feedback, explicit feedback as written explanation and implicit feedback, especially underlying and circling were presented to them. In week 15, they completed the questionnaire online comprising twenty items (five-Likert scales), and then they have expressed their reflections through five opened questions.

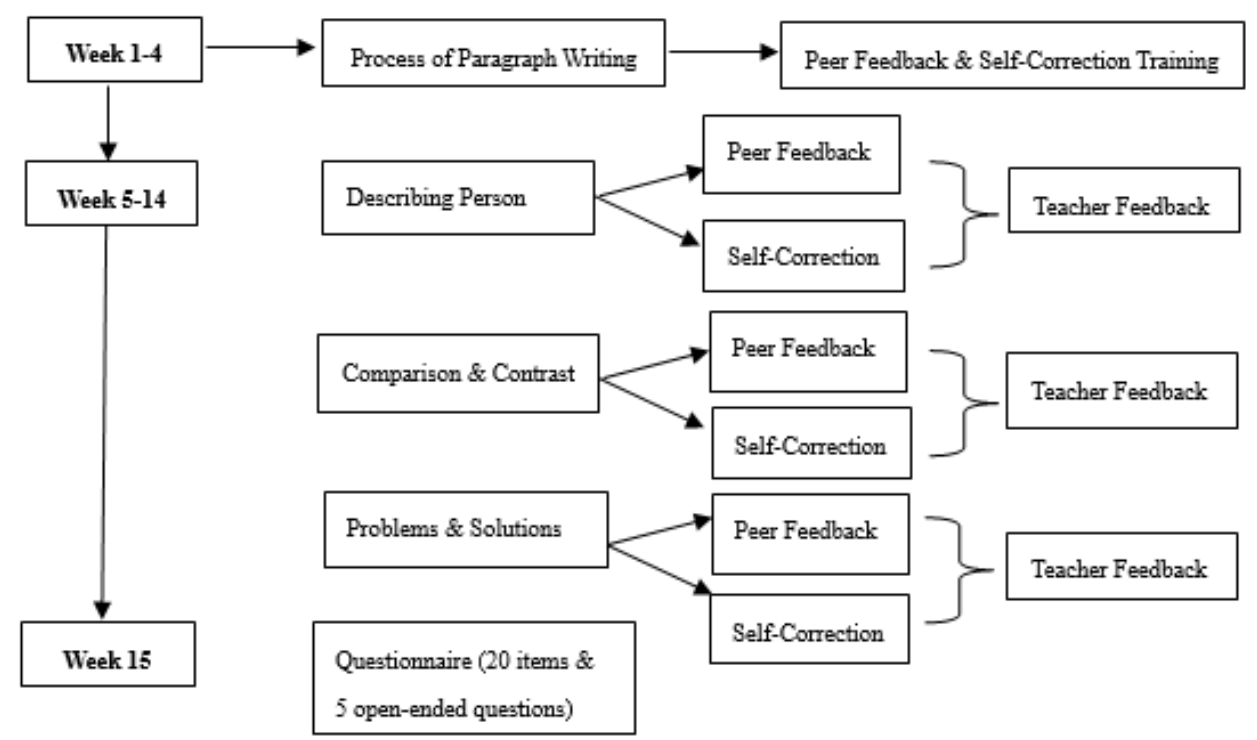

Figure 2. The procedure of Data Collection

\subsection{Data Analysis}

\subsubsection{Quantitative Data}

To analyze and transcribe students' perceptions through three writing features of teacher feedback, mean $(\bar{x})$ and standard deviation (SD) in SPSS-Version 24 were deployed. The results then were consequently interpreted as the mean score in each item. Furthermore, a paired sample t-test was utilized for the difference among three pairs: self-correction \& peer feedback, peer feedback \& teacher feedback, and self-correction \& teacher feedback. To ascertain the difference between implicit feedback and explicit feedback, a paired sample t-test was employed as well. 


\subsubsection{Qualitative Data}

As for personal responses towards teacher feedback, peer feedback, and self-correction, all obtained data were thematically categorized into four perspectives comprising (1) advantages of teacher feedback (2) peer feedback (3) self-correction, and (4) the most constructive feedback in EFL writing course.

\section{Results}

\subsection{Quantitative Results}

\subsubsection{Perceptions of teacher feedback}

Concerning the results of participants' perceptions towards teacher feedback, the interpretation of the mean score was adopted by Kitjaroonchai (2012), including very low (1.00-1.49), low (1.50-2.49), average (2.50-3.49), high 3.50-4.49) and very high (4.50-5.00) respectively.

Table 1. Three writing features of teacher feedback

\begin{tabular}{lccl}
\hline Writing Domains & $\overline{\mathbf{x}}$ & SD & Meaning \\
\hline Vocabulary & 4.75 & .508 & Very high \\
\hline Grammar & 4.59 & .499 & Very high \\
\hline Content & 4.62 & .554 & Very high \\
\hline Overall & $\mathbf{4 . 6 5}$ & $\mathbf{. 5 2 0}$ & Very high \\
\hline
\end{tabular}

As illustrated in table 1, participants entirely have positively perceptions towards teacher feedback in terms of three primary perspectives comprising vocabulary, grammar, and content on their three modes of writing assignments at the average mean score of 4.65 . When comparing the mean scores to the three different features, the highest mean score was the vocabulary domain $(\bar{x}=4.75, S D=.508)$. This asserted that lexical items played a pivotal role in English writing at the beginning stage. Furthermore, they firmly believed that teacher feedback given on content was helpful to greatly develop their writing drafts $(\overline{\mathrm{x}}=4.62, \mathrm{SD}=.554)$, and lastly, followed by the grammar domain receiving the least mean score $(\bar{x}=4.59, S D=.499)$. However, they still had very positive views of this domain. It affirmed that the teacher's suggestions on grammatical errors have been inevitable when students individually generated their paragraphs. Assuredly, three domains of teacher feedback were as crucial scaffold on writing at the early stage of the student writers.

\subsubsection{Comparisons among the three writing feedback}

The three types of writing feedback were paired into three groups consisting of self-correction \& peer feedback, peer feedback \& teacher feedback, and self-correction \& teacher feedback. Every single pair was analyzed by a paired-samples t-test, as in table 2 .

Table 2. Comparisons of teacher feedback, peer feedback, and self-correction

\begin{tabular}{|c|c|c|c|c|c|c|c|c|}
\hline \multirow{2}{*}{ Feedback } & \multirow{2}{*}{$\mathbf{n}$} & \multirow{2}{*}{$\overline{\mathbf{x}}$} & \multirow{2}{*}{ SD } & \multicolumn{2}{|c|}{$95 \%$ Confidence Interval of the difference } & \multirow{2}{*}{ t-value } & \multirow{2}{*}{ p-value } & \multirow{2}{*}{ df } \\
\hline & & & & Lower & Upper & & & \\
\hline Self & 32 & 4.44 & .564 & \multirow{2}{*}{.227} & \multirow{2}{*}{.711} & \multirow{2}{*}{3.950} & \multirow{2}{*}{$0.000^{*}$} & \multirow{2}{*}{31} \\
\hline Peer & 32 & 3.97 & .595 & & & & & \\
\hline $\begin{array}{l}\text { Peer } \\
\text { Teacher }\end{array}$ & $\begin{array}{l}32 \\
32\end{array}$ & $\begin{array}{l}3.97 \\
4.47\end{array}$ & $\begin{array}{l}.595 \\
.621 \\
\end{array}$ & -.775 & -.225 & $-3 \cdot 712$ & $0.001^{*}$ & 31 \\
\hline $\begin{array}{l}\text { Self } \\
\text { Teacher }\end{array}$ & $\begin{array}{l}32 \\
32\end{array}$ & $\begin{array}{l}4.44 \\
4.47\end{array}$ & $\begin{array}{l}.564 \\
.621 \\
\end{array}$ & -.282 & .219 & -.254 & $0.801^{*}$ & 31 \\
\hline
\end{tabular}

Note. *p $<0.05$ 
According to table 2 presented above, the results indicated that there was a statistically significant difference between self-correction and peer feedback, $\mathrm{t}(31)=3.95, \mathrm{p}=0.000,95 \% \mathrm{CI}(0.23,0.71)$. Notably, the average score of self-correction $(\bar{x}=4.44)$ was higher than peer feedback $(\bar{x}=3.97)$. This showed that participants have greatly preferred self-editing to peer revision. Similarly, the difference between the peer feedback and the teacher feedback appeared statistically significant, $\mathrm{t}(31)=-3 \cdot 71, \mathrm{p}=$ $0.001,95 \%$ CI $(-0.78,-0.23)$. The average score of the peer feedback $(\bar{x}=3.97)$ seemed less than the teacher feedback $(\bar{x}=4.47)$. It confirmed that between the two feedback, the teacher comment was quite more acceptable than others. Conversely, there was no statistically significant difference between the self-correction and the teacher feedback. Both showed the similarity of the average scores at 4.44 and 4.47 respectively. Participants believed that self-correction was as effective as teacher feedback in English writing course.

\subsubsection{Comparison between an implicit and an explicit feedback}

Here are two types of teacher writing suggestions include an implicit and an explicit feedback. The difference between the two was analyzed by a paired-samples t-test presented in table 3 .

Table 3: Difference between an implicit feedback and an explicit feedback

\begin{tabular}{|c|c|c|c|c|c|c|c|c|}
\hline \multirow{2}{*}{ Feedback } & \multirow{2}{*}{$\mathbf{n}$} & \multirow{2}{*}{$\overline{\mathbf{x}}$} & \multirow{2}{*}{ SD } & \multicolumn{2}{|c|}{$95 \%$ Confidence Interval of the difference } & \multirow{2}{*}{ t-value } & \multirow{2}{*}{ p-value } & \multirow{2}{*}{ df } \\
\hline & & & & Lower & Upper & & & \\
\hline $\begin{array}{l}\text { Implicit } \\
\text { Explicit }\end{array}$ & $\begin{array}{l}32 \\
32\end{array}$ & $\begin{array}{l}3.78 \\
4.62\end{array}$ & $\begin{array}{l}.608 \\
.554\end{array}$ & -.1 .120 & -.567 & -6.226 & $0.000^{*}$ & 31 \\
\hline
\end{tabular}

Note. ${ }^{*} \mathrm{p}<0.05$

As can be seen in table 3, it was found that there was a statistically significant difference between implicit feedback and explicit feedback, t $(31)=-6.23, \mathrm{p}=0.000,95 \% \mathrm{CI}(-1.12,-0.57)$. The explicit feedback $(\bar{x}=4.62)$ had a greater mean score than the implicit feedback $(\bar{x}=3.78)$. As for teacher feedback, the explicit feedback turned out to be more constructive than the implicit one to EFL beginning writers.

\subsection{Qualitative Results}

The present study adopted triangulation to strengthen the reliability and validity of the results. If obtained data of twenty item-questionnaire corresponded to qualitative data of five open-ended questions in terms of similar perspectives, it would help answer the research questions that could not be answered by quantitative or qualitative methods alone (Creswell, 2014). The results illustrated various responses and reflections into four main themes: advantages of teacher feedback, peer feedback, self-correction assisting in writing revision process, and the most productive feedback in writing courses for writing beginners. All categories were composed of frequency and percentage as shown in table 4 .

Table 4. Perception towards teacher feedback, peer feedback, and self-correction $(\mathrm{n}=32)$

\begin{tabular}{|c|c|c|c|c|c|c|c|}
\hline \multicolumn{8}{|c|}{ Theme 1: Advantages of Teacher Feedback } \\
\hline \multicolumn{8}{|c|}{ Three writing domains } \\
\hline $\begin{array}{l}\text { - Grammar (26): } \\
\text {-better understanding of } \\
\text { English structure(14) }\end{array}$ & $\begin{array}{l}81.25 \% \\
43.75 \%\end{array}$ & $\begin{array}{l}\text { - Vocabulary (21): } \\
\text {-more insight into } \\
\text { word choice (9) }\end{array}$ & $\begin{array}{l}65.63 \% \\
28.13 \%\end{array}$ & $\begin{array}{l}\text { - Content (16): } \\
\text {-more better } \\
\text { paragraph (5) }\end{array}$ & \multicolumn{2}{|c|}{$\begin{array}{c}50 \% \\
15.63 \%\end{array}$} & \\
\hline \multicolumn{8}{|c|}{ Types of Writing Correction } \\
\hline $\begin{array}{l}\text { - Teacher's } \\
\text { explanation } \\
(24):\end{array}$ & $75 \%$ & $\begin{array}{l}\text {-brighter writing } \\
\text { guideline (12) }\end{array}$ & $37.25 \%$ & $\begin{array}{l}\text {-useful examples } \\
(10)\end{array}$ & $31.25 \%$ & $\begin{array}{l}\text {-productive } \\
\text { suggestions for } \\
\text { other writing } \\
\text { tasks(8) }\end{array}$ & $25 \%$ \\
\hline \multicolumn{2}{|c|}{ - Underlining \& Circling (10): } & $31.25 \%$ & \multicolumn{4}{|c|}{-perceiving repetitive words \& ambiguous sentences (4) } & $12.5 \%$ \\
\hline
\end{tabular}




\begin{tabular}{|c|c|c|c|c|c|c|c|c|}
\hline \multicolumn{9}{|c|}{ Theme 2: Peer Feedback (be productive?) } \\
\hline - Yes (31) & $96.88 \%$ & $\begin{array}{l}\text {-assisting } \\
\text { better } \\
\text { writing draft } \\
(17)\end{array}$ & $53.13 \%$ & \begin{tabular}{|c|} 
- exchange \\
of ideas \\
(9)
\end{tabular} & $28.13 \%$ & \multicolumn{2}{|c|}{$\begin{array}{l}\text {-misspelling \& punctuation } \\
\text { correction } \\
\text { (7) }\end{array}$} & $21.88 \%$ \\
\hline$\because \mathrm{No}(1)$ & $3.12 \%$ & $\begin{array}{l}\text {-unproductive } \\
\text { feedback (1) }\end{array}$ & $3.12 \%$ & & & & & \\
\hline \multicolumn{9}{|c|}{ Theme 3: Self-Correction } \\
\hline \multicolumn{3}{|c|}{$\begin{array}{l}\text { - Better chance of revising } \\
\text { \& editing own draft (29): }\end{array}$} & $90.63 \%$ & \multicolumn{4}{|c|}{$\begin{array}{l}\text { Being more confident } \\
\text { \& careful in English writing (17) }\end{array}$} & $53.13 \%$ \\
\hline \multicolumn{9}{|c|}{ Theme 4: The most constructive Feedback in EFL Writing Course } \\
\hline \multicolumn{2}{|c|}{$\begin{array}{l}\text { Teacher Feedback } \\
\text { (15): }\end{array}$} & $46.88 \%$ & $\begin{array}{l}\text { - Teacher, Peer } \\
\text { Feedback } \\
\text { \& Self-Correction (7): }\end{array}$ & $21.88 \%$ & $\begin{array}{l}\text { - Self-Correction } \\
(4) \text { : }\end{array}$ & $12.5 \%$ & \begin{tabular}{|l} 
- Teacher \& \\
Peer Feedback (4):
\end{tabular} & $12.5 \%$ \\
\hline \multicolumn{2}{|c|}{$\begin{array}{l}\text {-providing accurate and } \\
\text { professional comments } \\
(12)\end{array}$} & $37.5 \%$ & $\begin{array}{l}\text {-insightful writing } \\
\text { editing (3) }\end{array}$ & $9.38 \%$ & $\begin{array}{l}\text {-getting more } \\
\text { precise writing } \\
\text { draft on their } \\
\text { revision (4) }\end{array}$ & $12.5 \%$ & $\begin{array}{l}\text {-giving illustrating } \\
\text { lexical \& } \\
\text { grammatical } \\
\text { errors (4) }\end{array}$ & $12.5 \%$ \\
\hline \multicolumn{2}{|c|}{$\begin{array}{l}\text {-being a skillful } \\
\text { facilitator in writing (5) }\end{array}$} & $15.63 \%$ & $\begin{array}{l}\text {-being meaningful } \\
\text { for English writing } \\
\text { development }(5)\end{array}$ & $15.63 \%$ & & & & \\
\hline
\end{tabular}

Regarding the advantages of the teacher feedback in theme 1 , it was wholly composed of two domains: three writing features as well as types of writing correction. It could be explained in detail as in the first domain of teacher feedback, the three writing perspectives, including grammar, vocabulary, and content. The overall findings reported that $81.25 \%$ of participants believed that giving teacher feedback on grammar was beneficial to editing their writing tasks. They had a better understanding of English structure as well $(43.75 \%)$. Importantly, vocabulary was the next writing domain of teacher feedback they needed to deal with their writing drafts $(65.63 \%)$. It was due to the fact that they could gain many more word choices at $\mathbf{2 8 . 1 3} \%$. It also revealed half of the participants felt that the teacher's ideas provided on content were fruitful since they had an ability of conveying their thoughts more comprehensibly through their paragraphs (15.63\%).

Concerning the topologies of teacher writing correction, it can notably see that $75 \%$ of them ensured that the teacher's explanation considerably assisted them in their writing improvement as they mastered brighter writing suggestions (37.25\%). In other points of views, they were capable of receiving productive examples and recommendations in further writing assignments at $31.25 \%$ and $25 \%$ respectively. Likewise, another type of teacher correction was underlining \& circling (31.25\%). They felt certain that the underlining of writing errors was wordy and ambiguous feedback (12.5\%).

According to theme 2, it covered to what extent peer feedback was productive in writing. $96.88 \%$ of participants agreed with this since it could be able to support better writing drafts (53.13\%). Furthermore, they had chances to contribute their ideas (28.13\%) and errors in terms of word spelling and missing punctuation (21.88\%). Nevertheless, only one of them believed that peer feedback was a kind of useless approach (3.12\%).

Additionally, the third theme consisted of several reasons of employing self-correction on writing revision. 90.63\% of them expressed that it would be better to be provided many more opportunities in their writing redrafts so that they could raise more self-confidence and carefulness in redrafting their paragraphs (53.13\%).

The last theme referred to what the most constructive feedback is in EFL writing classroom. The findings were displayed into four dimensions: teacher feedback, teacher \& peer feedback \& selfcorrection, and teacher \& peer feedback. According to the overall results, the acceptance of the teacher comments was the most appreciated feedback method (46.88\%). It was owing to the fact that teachers often provided reliable and understandable feedback as a professional (37.5\%) and a skillful facilitator $(15.63 \%)$ in editing their writing tasks. $21.88 \%$ of them positively perceived the teacher feedback, the peer feedback \& self-correction because all the three approaches were meaningful in English writing development (15.63\%). As for other two feedback domains, including self-correction (12.5\%) and the teacher \& the peer feedback (12.5\%), students have got more insightful writing drafts on their revisions (12.5\%), and they also thought that both teacher's and their friends' feedback precisely showed them 
errors in grammatical and lexical aspects (12.5\%).

\section{Discussion}

The current study utilized quantitative data by the means of a five-point Likert scale questionnaire and qualitative data through five open-ended questions. A combination of the two as a mixed-method provided a better insight into research questions and results rather than employing a single research approach (Creswell, 2014). As for the obtained data, the findings manifested three primary perspectives: perceptions through three writing domains, comparisons among teacher feedback, peer feedback, and self-correction as well as the difference between implicit and explicit feedback from a teacher.

\subsection{Perceptions through the three writing features of teacher feedback}

Students positively perceived teacher feedback in terms of three main writing elements including lexical items, grammatical structures, and contents on their writing assignments. Comparing among the three writing domains, it assured that vocabulary has become one of the most crucial writing components to student writers to broaden writing ability and generate well-structured written paragraphs (Karakoç \& Köse, 2017; Viera, 2017). Vocabulary knowledge has had an obvious impact on writing for it could help in improve writing skill at tertiary level (Leki, 1991). With regard to the qualitative results of these three writing domains, students would be more insightful into word choices because of written corrective teacher feedback on their drafts. Additionally, students realized that English grammar competence has also turned to be essential in writing. Grammatical accuracy has still been a writing problem in EFL context since several previous studies emphasized that writing errors frequently appeared in students' writing pieces (Sommanochai \& Meesri, 2018). Students believed that teacher comments on grammar might allow them to have a better understanding of English sentence structure and language use. Contents and ideas of paragraph writing have also influenced the beginning of composing a paragraph (AlTameemy \& Daradkeh, 2019) as crucial as other two mentioned writing elements. Teacher's suggested ideas might strengthen their drafts more comprehensibly and precisely. Concerning Straub's (1997) result, it confirmed that receiving feedback on both global issues (i.e. content, purpose, and organization) and primary ones (i.e. word choice, grammar, and sentence structure) were expected to emerge on students' writing drafts. Encouraging written corrective teacher feedback at the beginning stage of writing could significantly decrease errors over time (Hyland \& Hyland, 2006; Hyland \& Hyland, 2019). Consequently, it could be concluded that providing teacher feedback in terms of vocabulary, grammar, and content on writing revision is a fairly important component enhancing and developing student's writing ability.

\subsection{Comparisons among the three main writing feedback}

According to the quantitative and qualitative findings of the present study suggested that among the three writing feedback including the teacher feedback, the peer feedback, and self-correction, students' most writing feedback preference was the teacher feedback. They believed that the teacher written comments were more accurate than the other feedback. The teacher seemed to be a professional facilitator similar to Ekși's (2012) and Sengupta's (1998) results which claimed that the teacher was an expert in writing correction whereas their friends would not be knowledgeable enough to figure out their writing errors. Teachers have also raised students' writing motivation as well. These concurred to Srichanyachon's (2012) and Zacharias's (2007) studies, which highlighted teacher feedback to be more effective, facilitated in EFL students writing revision process as well as positively contributed their attitudes towards writing. In many EFL and/or ESL contexts, particularly in large undergraduate classes, teacher feedback has remained a major role of feedback in writing courses (Lee, 2017). In addition, compared to peer's feedback and self-correction, the teacher comments were merely more acceptable than the other two. This was evidenced by an empirical study of Ferris and Roberts (2001), 
their result illustrated that students expected teacher to provide comments on their drafts in terms of written errors and they were disappointed if this did not occur.

Correspondingly, peer feedback was perceived and preferred less than teacher feedback and selfcorrection on writing revision in accordance with the quantitative results of the questionnaire. Different from the qualitative findings of an open-ended question, students' responses manifested highly positive thoughts towards peer feedback due to the fact that their classmates could help their writing draft better as Hyland and Hyland (2006) assured effective peer editing could help novice writers to comprehend how readers see their works. Moreover, they had greater opportunities to freely share their ideas as well as some language errors, namely misspelling, and punctuation which were corrected by their peers. These were in line with Allen \& Katayama's (2016), Kuyyogsuy's (2019), and Yu \& Hu's (2017) findings which vividly delineated that EFL students positively perceived peer feedback at a high level on writing revision. They were capable of attaining grammatical sentences and vocabulary accuracy as well as contributing ideas to other students to the more comprehensible passage of redrafting (Wang, 2014; Yastıbaş \& Yastıbaş, 2015).

Additionally, it is accepted that self-correction on writing draft can be another optional writing feedback preference regarding both quantitative and qualitative obtained data. Students mostly felt that they were provided more opportunities on editing their drafts by themselves as well as became more confident and careful in English writing. As for Amelia's (2020) study, her result claimed that students, who could have chances of editing writing errors on their own decision, were able to succeed in the maximum result of learning. In other words, more proficient students should be given more time of self-correction while teacher feedback had better be provided to less proficient ones. The findings of Honsa (2013) and Meihami \&Varmaghani (2013) recommended that self-correction be capable of significant improving EFL students' writing revision and promote autonomous proficient writing skills.

With regard to the most meaningful writing feedback among EFL beginning writers, the teacher feedback was assuredly the most writing feedback preference as mentioned above. Neveertheless, they believed that a combination of the three writing feedback consisting of teacher feedback, peer feedback, and self-correction were needed as pivotal writing feedback on their redrafts as well since receiving writing comments from the three sources supported better insight, more accurate and confident conveying messages in the form of written English passages. These agreed with Evans \& Ferris's (2019), Mawlawi Diab's (2016), and Vasu, Ling \& Nimehchisalem's (2016) studies, which revealed students were highly aware of the benefits of the three feedback. It was essential to teachers monitoring students' writing tasks and proving suggestions. Hence, student writers carefully revised their drafts on their productive ways as well as their classmates' feedback. They would be slightly confident to automatically deal with their writing revisions themselves. As Anderson's (1993) three stages of language learning process emphasized students to have firstly perceived some grammar rules and then have to learn how to use them. Finally, they are able to autonomously apply them to learn a target language in a particular context.

\subsection{Difference between an implicit and an explicit feedback}

Concerning an implicit and an explicit feedback provided by teacher, the implicit feedback has been given by means of circling, underlining, code, and so forth whereas the explicit correction was related to teacher's written explanation on word choices, grammatical structures, cohesion, and other syntactic aspects. Regarding the findings of the study in the light of two types of teacher feedback, qualitative obtained data displayed that students were likely to explicitly receive feedback rather than be given comments implicitly. This has firmly supported the quantitative results in harmonious perspective which were in line with several studies (e.g. Ahmadi, Maftoon \& Mehrdad, 2012; Ferris, 2006; Fhaeizdhyall, 2020; Hosseiny, 2014; Karim \& Nassaji, 2018) which indicated that students deployed the explicit feedback more consistently and effectively than the implicit feedback. They could improve their language accuracy during the revision of passage composition. Moreover, they truly exposed that teacher's explanation broadened how to write up English sentences and employed transitions more 
accurately and appropriately. Tangkiengsirisin and Kalra (2016) assured that providing direct corrective feedback promoted positive outcomes on the grammatical accuracy of students' writing assignments. Explicit feedback was students' preference over time due to the fact that they simply imitated and copied teacher's suggestions into their later draft (Ferris, 2006). On the other hand, teacher feedback, particularly circling and/or underlining written errors without any teacher's commentary was their less preference in their writing drafts. This has misled students into wrong and ambiguous ideas of generating their paragraph in English similar to Hosseiny's (2014) and Tangkiengsirisin \& Kalra's (2016) findings showing that the indirect feedback made them confused when the teacher only circled or underlined their writing errors. Students no longer had any opportunities to enhance writing skills because they did not receive proper feedback at the beginning stage of writing. Notably, providing teacher's implicit and explicit feedback to students sometimes depends on students' English proficiency. It would be considered that lower proficiency might not be able to cooperate with implicit writing errors by themselves (Ferris \& Hedgcock, 2005; Rustipa, 2014). In other words, implicit feedback is likely to challenge more proficient students on their writing revision process.

\section{Conclusion and Pedagogical Implications}

The findings of the current study illustrated that novice writers have positively perceived teacher's suggestions as their writing preference in their paragraph revision than peer feedback and selfcorrection. During the beginning of the writing process, word choices, accurate grammatical sentences, and brighter ideas of the content were expected to be provided by the teacher. It is worth pointing out that the teacher plays a partial pivotal role as a facilitator and an expert to encourage beginning writers through explicit feedback rather than implicit one owing to the fact that they have had less writing experiences in English as well as less syntactical knowledge. Students, therefore, have gradually improved and have had better results in writing production. Importantly, the present study's findings vividly suggested that beginning writers would not necessarily be given only teacher feedback in a writing classroom; however, the combination of the three feedbacks could be more effective and constructive on writing revision stage as well. In Thailand and other Asian countries, EFL/ESL proficient students can correct their peer's misspelling, punctuation and/or proper transitions. Teachers should continuously provide more opportunities to students to work collaboratively with other classmates. Editing their writing assignments by their own decision would promote them to be more confident and eventually become more autonomous writers. These would bring a harmonious environment into a writing classroom. The positive atmosphere in the classroom could motivate not only the teacher but also the students to engage in the target language assignments more efficiently. It can be concluded that the results of the study would shed light on the alternative preference by novice writers in editing their writing and better undertaking in terms of implementing various correcting feedback to English writing context.

Concerning the limitations of the study, it has recently investigated only one side of students' perceptions of writing feedback. It has also employed only questionnaires and open-ended questions to gather quantitative as well as qualitative data among purposive samples. Further studies should determine teachers' and students' perspectives on giving and receiving written corrective feedback on a larger number of samples at tertiary level. Additionally, it should collect qualitative data from teachers' and students' interviews and writing classroom observations in the light of different writing strategies deployed in writing pedagogy. It would eventually bring much greater understanding of better English writing improvement into ESL/EFL undergraduate classrooms in Asian countries and across the globe.

\section{References}

AbuSeileek, A., \& Abualsha'r, A. (2014). Using peer computer-mediated corrective feedback to support EFL learners' writing. Language Learning \& Technology, 18(1), 76-95. 
Ahmadi, D., Maftoon, P., \& Mehrdad, A. G. (2012). Investigating the Effects of Two Types of Feedback on EFL Students' Writing. Procedia - Social and Behavioral Sciences, 46, 2590-2595. Available at: https://doi:10.1016/j.sbspro.2012.05.529.

Allen, D., \& Katayama, A. (2016). Relative second language proficiency and the giving and receiving of written peer feedback. System, 56, 96-106. Available at: https://doi:10.1016/j.system.2015.12.002.

Allen, D., \& Mills, A. (2014). The impact of second language proficiency in dyadic peer feedback. Language Teaching Research, 20(4), 498-513. Available at: https://doi:10.1177/1362168814561902.

AlTameemy, F., \& Daradkeh, A. (2019). Common Paragraph Writing Errors Made by Saudi EFL Students: Error Analysis. Theory and Practice in Language Studies, 9(2), 178. Available at: https://doi:10.17507/tpls.0902.07.

Amelia, R. (2020). Students' perception on employing self-directed feedback in writing. Journal of Applied Linguistics $\mathcal{E}$ Literature, 5(1), 60-70. Available at: https:/doi:10.33369/joall.v5i1.10151.

Amelia, R., Latief, M. A., \& Irawati, E. (2018). The Combination of Peer and Self-directed Feedback on Writing Ability of EFL High Proficient Students. Jurnal Pendidikan Humaniora, 6(2), 91-98. Available at: https://doi:10.2991/seadric-17.2017.17.

Anderson, J. (1993). Rules of the mind. Hillsdale, New Jersey: Lawrence Erlbaum.

Belachew, M., Getinet, M., \& Gashaye, A. (2015). Perception and Practice of Self-Assessment in EFL Writing Classrooms. Journal of Languages and Culture, 6(1), 1-8. Available at: https://doi:10.5897/jlc2013.0254.

Bitchener, J., \& Ferris, D. R. (2012). Written Corrective Feedback in Second Language Acquisition and Writing. New York: Routledge.

Cahyono, B., \& Rosyida, A. (2016). Peer feedback, self-correction, and writing proficiency of Indonesian EFL students. Arab World English Journal (AWEJ), 7(1), 178-193. Available at: https:/doi:10.24093/awej/vol7no1.12.

Creswell, J. W. (2014). Research design: qualitative, quantitative, and mixed methods approaches. Thousand Oaks, CA: SAGE.

Edwards, J. H., \& Liu, J. (2018). Peer response in second language writing classrooms. Michigan: University of Michigan Press.

Ekşi, G. Y. (2012). Peer review versus teacher feedback in process writing: How effective. International Journal of Applied Educational Studies, 13(1), 33-48.

Evans, K., \& Ferris, D. (2019). Revision from Multiple Feedback Sources: The Attitudes and Behaviors of Three Multilingual Student Writers. Research in the Teaching of English, 54(2), 131-160.

Fareed, M., Ashraf, A., \& Bilal, M. (2016). ESL learners' writing skills: Problems, factors and suggestions. Journal of Education and Social Sciences, 4(2), 81-92. Available at: https://doi.org/10.20547/jesso421604201.

Ferris, D. R. (2006). Does error feedback help student writers? New evidence on the short-and long-term effects of written error correction. Feedback in Second Language Writing, 81-104. Available at: https://doi:10.1017/cbo9781139524742.007.

Ferris, D. R., \& Hedgcock, J. (2005). Teaching ESL composition: Purpose, process, and practice. Mahwah, NJ: Lawrence Erlbaum.

Ferris, D., \& Roberts, B. (2001). Error feedback in L2 writing classes: How explicit does it need to be?. Journal of second language writing, 10(3), 161-184. Available at: https://doi:10.1016/s106o-3743(o1)ooo39-x.

Fhaeizdhyall, A. (2020). The Effectiveness of Direct and Indirect Written Corrective Feedback on English Collocation Competency: A Quasi - Experiment. Journal for the Study of English Linguistics, 8(1), 94-114. Available at: https://doi:10.5296/jsel.v8i1.16434.

Han, Y., \& Hyland, F. (2015). Exploring learner engagement with written corrective feedback in a Chinese tertiary EFL classroom. Journal of Second Language Writing, 30, 31-44. Available at: https://doi:10.1016/j.jslw.2015.08.002

Honsa, S. (2013). Self-assessment in EFL writing: A study of intermediate EFL students at a Thai university. Voices in Asia Journal, 1(1), 34-57.

Hosseiny, M. (2014). The role of direct and indirect written corrective feedback in improving Iranian EFL students' writing skill. Procedia-Social and Behavioral Sciences, 98, 668-674. Available at: https://doi:10.1016/j.sbspro.2014.03.466.

Hyland, K., \& Hyland, F. (2006). Feedback on second language students' writing. Language teaching, 39(2), 83-101.

Hyland, K., \& Hyland, F. (Eds.). (2019). Feedback in second language writing: Contexts and issues. Cambridge: Cambridge University Press.

Judto, J. (2014). The What and The How of Feedback in ESL and EFL Writing: What Research Says. Journal of Liberal Arts Ubon Ratchathani University, 10(2), 51-76.

Karakoç, D., \& Köse, G. D. (2017). The impact of vocabulary knowledge on reading, writing and proficiency scores of EFL learners. Journal of language and linguistic studies, 13(1), 352-378. 
Karim, K., \& Nassaji, H. (2018). The revision and transfer effects of direct and indirect comprehensive corrective feedback on ESL students' writing. Language Teaching Research, 24(4), 519-539. Available at: https://doi:10.1177/1362168818802469.

Kaur, S. (2015). Teaching strategies used by Thai EFL lecturers to teach argumentative writing. Procedia-Social and Behavioral Sciences, 208, 143-156. Available at: https://doi:10.1016/j.sbspro.2015.11.191.

Kitjaroonchai, N. (2012). Motivation toward English language learning of Thai students majoring in English at AsiaPacific International University. Human Behavior, Development and Society, 7(1), 21-40.

Kuyyogsuy, S. (2019). Students' Attitudes Toward Peer Feedback: Paving a Way for Students' English Writing Improvement. English Language Teaching, 12(7), 107-119. Available at: https://doi:10.5539/elt.v12n7p107.

Landry, A., Jacobs, S., \& Newton, G. (2014). Effective Use of Peer Assessment in a Graduate Level Writing Assignment: A Case Study. International Journal of Higher Education, 4(1). Available at: https://doi:10.5430/ijhe.v4nip38.

Lee, I. (2017). Teacher Feedback in L2 Writing. In: Classroom Writing Assessment and Feedback in L2 School Contexts. Singapore: Springer. Available at: https://doi.org/10.1007/978-981-10-3924-9_6.

Leki, I. (1991). The Preferences of ESL Students for Error Correction in College Level Writing Classes. Foreign Language Annals, 24(3), 203-218. Available at: https://doi:10.1111/j.1944-9720.1991.tboo464.X.

Maarof, N., Yamat, H., \& Li, K. L. (2011). Role of teacher, peer and teacher-peer feedback in enhancing ESL students' writing. World Applied Sciences Journal, 15(Innovation and Pedagogy for Lifelong Learning), 35-29.

Mahfoodh, O. H. A. (2017). "I feel disappointed": EFL university students' emotional responses towards teacher written feedback. Assessing Writing, 31, 53-72. Available at: https://doi:10.1016/j.asw.2016.07.001.

Mawlawi Diab, N. (2016). A comparison of peer, teacher and self-feedback on the reduction of language errors in student essays. System, 57, 55-65. Available at: https://doi:10.1016/j.system.2015.12.014.

Meihami, H., \& Varmaghani, Z. (2013). The Implementation of Self-Assessment in EFL Writing Classroom: An Experimental Study. International Letters of Social and Humanistic Sciences, 9, 39-48. Available at: https://doi:10.18052/www.scipress.com/ilshs.9.39

MiraCosta College (2012). Writing Assessment: Paragraph. [Online] Available: https://www.miracosta.edu /instruction/continuingeducation/esl/downloads/IntermedLevelWritingAssess.pdf. (3 June 2020).

Nielsen, K. (2012). Self-assessment methods in writing instruction: a conceptual framework, successful practices and essential strategies. Journal of Research in Reading, 37(1), 1-16. Available at: https://doi:10.1111/j.14679817.2012.01533.X.

Patchan, M. M., Schunn, C. D., \& Correnti, R. J. (2016). The nature of feedback: How peer feedback features affect students' implementation rate and quality of revisions. Journal of Educational Psychology, 108(8), 1098-1120. Available at: https://doi:10.1037/eduoooo103.

Phuket, P. R. N., \& Othman, N. B. (2015). Understanding EFL Students' Errors in Writing. Journal of Education and Practice, 6(32), 99-106.

Ruegg, R. (2015). Differences in the Uptake of Peer and Teacher Feedback. RELC Journal, 46(2), 131-145. Available at: https://doi:10.1177/o033688214562799.

Rustipa, K. (2014). The Effectiveness of Direct and Indirect Written Corrective Feedback in Improving EFL Learners' Hortatory Exposition Writing. In TEFLIN International Conference 2014.

Sengupta, S. (1998). Peer evaluation: "I am not the teacher". ELT Journal, 52(1), 19-28. Available at: https://doi:10.1093/eltj/52.1.19.

Sommanochai, S., \& Meesri, R. (2018). The Study of Written Corrective Feedback on Grammatical Accuracy in The English Paragraph Writing of Grade 12 Students. Online Journal of Education, 13(2), 441-456.

Srichanyachon, N. (2012). An investigation of university EFL students attitudes toward peer and Teacher feedback. Educational Research and Reviews, 7(26), 558-562.

Straub, R. (1997). Students' reactions to teacher comments: An exploratory study. Research in the Teaching of English, 31(1), 91-119.

Tangkiengsirisin, S., \& Kalra, R. (2016). Thai Students' Perceptions on the Direct Vs. Indirect Written Corrective Feedback: A Thai University Context. Arab World English Journal, 7(3), 161-176. Available at: https://doi:10.24093/awej/vol7no3.12.

Tongjean, W., Chusanachoti, R., \& Makanong, A. (2019). Development of an Instructional Model Based on InquiryBased Learning and 36o Degree Feedback Approaches to Enhance English Argumentative Writing Ability of Undergraduate Students. Journal of Education Studies, 47(3), 361-383.

Tuntavanitch, P., \& Jindasri, P. (2018). The Real Meaning of IOC. Journal of Educational Measurement Mahasarakham University, 24(2), 3-12. 
Vasu, K., Ling, C. H., \& Nimehchisalem, V. (2016). Malaysian tertiary level ESL students' perceptions toward teacher feedback, peer feedback and self-assessment in their writing. International Journal of Applied Linguistics and English Literature, 5(5), 158-170. Available at: https://doi:10.7575/aiac.ijalel.v.5n.5p.158.

Viera, R. T. (2017). Vocabulary knowledge in the production of written texts: a case study on EFL Language learners. Revista Tecnológica-ESPOL, 30(3). 89-105.

Wang, W. (2014). Students' perceptions of rubric-referenced peer feedback on EFL writing: A longitudinal inquiry. Assessing Writing, 19, 80-96. Available at: https://doi:10.1016/j.asw.2013.11.oo8.

Watcharapunyawong, S., \& Usaha, S. (2013). Thai EFL Students' Writing Errors in Different Text Types: The Interference of the First Language. English Language Teaching, 6(1), 67-78. Available at: https://doi:10.5539/elt.v6nip67.

Wirantaka, A. (2016). Paragraph Writing of Academic Texts in an EFL Context. Journal of Foreign Language Teaching and Learning, 1(2), 34-45. Available at: https://doi:10.18196/ftl.1212.

Yastıbaș, G. Ç., \& Yastıbaș, A. E. (2015). The effect of peer feedback on writing anxiety in Turkish EFL (English as a foreign language) students. Procedia-Social and Behavioral Sciences, 199, 530-538. Available at: https://doi:10.1016/j.sbspro.2015.07.543.

Yu, S., \& Hu, G. (2017). Understanding university students' peer feedback practices in EFL writing: Insights from a case study. Assessing Writing, 33, 25-35. Available at: https://doi:10.1016/j.asw.2017.03.004.

Zacharias, N. T. (2007). Teacher and student attitudes toward teacher feedback. RELC journal, 38(1), 38-52.

Zemach, D. E., \& Rumisek, L. A. (2018). Writing Essays: from paragraph to essay. Thailand: Macmillan Publishers.

Zhang, Z. (Victor), \& Hyland, K. (2018). Student engagement with teacher and automated feedback on L2 writing. Assessing Writing, 36, 90-102. Available at: https://doi:10.1016/j.asw.2018.02.004.

Zheng, Y., \& Yu, S. (2018). Student engagement with teacher written corrective feedback in EFL writing: A case study of Chinese lower-proficiency students. Assessing Writing, 37, 13-24. Available at: https://doi:10.1016/j.asw.2018.03.001. 